\title{
GROWTH AND CROPPING OF TWO PEAR CULTIVARS AS AFFECTED BY THE TYPE OF NURSERY TREES
}

\author{
Ireneusz Stefan SOSNA* \\ Wrocław University of Environmental and Life Sciences \\ Norwida 25, 50-375 Wrocław, Poland \\ Received: June 2016; Accepted: October 2016
}

\begin{abstract}
The study was conducted in 2001-2012 next to Wrocław (south-western Poland). The purpose of this research was to assess the influence of type of nursery trees of pear cvs 'Carola' and 'Dicolor' budded on quince $S_{1}$ rootstock on growth and cropping, as well as fruit quality of two pear cultivars. The trees were planted in the spring of 2001 in 4 replications with 5 trees per plot. Trees were planted in rows with spacing $1.2 \times 3.5 \mathrm{~m}$ (2381 trees per hectare). Three types of nursery trees, all without feathers, were planted: twoyear-old ( 3 years in a nursery), one-year-old maidens ( 2 years in a nursery) and annual grafts (only 1 year in a nursery). Tree canopies were formed as a spindle and were trained in the Güttingen-V system. Until the twelfth year after planting, growth and yield were significantly affected by the type of nursery trees. One-year-old maidens were characterized by the strongest vigor in orchard, while pears planted as twoyear-old trees grew rather weak (especially with 'Dicolor' cv.). Planting two-year-old trees didn't have any clear positive influence on tree cropping in the orchard. The final results of the study proved that trees planted as annual grafts, irrespective of cultivar, yielded significantly worse. The type of nursery trees had no clear influence on mean fruit weight.
\end{abstract}

Key words: Pyrus communis, planting material, quality, growth, cropping

\section{INTRODUCTION}

The pear cultivation is less profitable than the apple cultivation and much more risky in terms of production. In comparison to apple trees, pear trees start bearing fruits later and their yield is worse. Pear trees have higher climate-soil requirements and their fruits show worse storage ability. The number of cultivars and rootstocks suitable for pear orchards is limited too (Sosna 2007).

The early and high productivity of pear trees first of all depends on cultivar and rootstock. Likewise, the quality of nursery trees is one of the most important factors when establishing an orchard. The profitability of any intensive pear orchard is related to its ability to produce early yield of fruit. This is highly dependent on planting high quality nursery trees, which have strong growth and will develop an adequate canopy structure in the early years after planting (Elkins et al. 2008). According to Deckers \& Schoofs (2001), for pear trees planted in high density planting systems, the quality of the planting material should be high, which can be provided by the two-year-old trees with 6 to 8 lateral branches obtained by repeated pruning of the one-year-old maidens in a nursery. There is an important difference in productivity between a one-year-old nonfeathered maiden and a two-year-old feathered tree during the first year after planting. When a oneyear-old whip is planted, the yield may be delayed by two years, during which the frame of the tree has to be developed. For intensive high density pear plantings, only two-year-old trees are recommended. Trees with lateral branches for intensive pear orchards provide high and early yield (Oosten 1978; Czynczyk 1989; Green 1991; Robinson 2003; Sadowski et al. 2007). As the benefits of highly feathered trees were discovered, it became necessary to 
develop nursery management techniques to stimulate lateral branch development (Robinson et al. 2014). The use of plant growth regulators has been seen as a good way of inducing lateral branching and cheaper than manual "leaf pinching" (Elfving \& Visser 2005; Kapłan 2010; Sazo \& Robinson 2011). In the Jacyna (2004) study, branching was better on dwarf Quince MA rootstock than on standard "Bartlett" seedling rootstock. Maiden pear trees have a limited branching capacity in comparison with the trees of other fruit species, such as apples or sour cherries. The planting material is produced in the nursery for 2 (one-year-old maidens) or for 3 years (two-year-old trees). By winter grafting, a two- or three-year cycle of production could be shortened to one year. This method might be cheaper than the traditional one and may reduce the stress connected with older trees transplanting (Ferree 1976). To decrease the harmful influence of transplanting on tree growth, more often (for example in Holland or Norway), the maiden trees are produced in plastic containers. These trees, without their root system damage, grow much better after planting in orchard (Czynczyk 1989).

The aim of the presented study was to compare the growth, yield and fruit quality of 2 pear cultivars in an orchard depending on the type and quality of planting material in the conditions of the Lower Silesia. The published results are based on data obtained during 12 years of research.

\section{MATERIALS AND METHODS}

The experiment was conducted at the Fruit Experimental Station in Samotwór near Wrocław (south-western part of Poland) in 2001-2012. The orchard was located on a fawn soil consisting of slightly sandy, light clay over medium clay and representing the IIIb class of the Polish economical soil classification. The research was carried out on the cvs 'Carola' and 'Dicolor' trees budded on the quince $S_{1}$ root stock and planted in spring of 2001 . These cultivars on dwarf rootstock are characterized by a rather strong growth, especially 'Dicolor', and high productivity. The planting pattern followed the randomized block design with four replications and 5 trees per plot. The in-row tree spacing was $1.2 \mathrm{~m}$ whereas the distance between rows equaled $3.5 \mathrm{~m}$ (2381 trees per hectare). The nursery trees varied in age from two-year-old trees (3 years in a nursery), one-year-old maidens ( 2 years in a nursery) and annual grafts (only 1 year in a nursery). The youngest trees were whips grafted during winter time, planted in a spring and dug out from the nursery in autumn of the same year. Irrespective of the planting material age, all trees had no lateral branches. Pear tree canopies were formed as a spindle with minimum pruning after blooming time and shoots maximally bending down by using concrete weights. The trees were trained in the Güttingen- $\mathrm{V}$ system. No irrigation was applied. The orchard floor management system consisted of herbicide fallow in the tree rows and sward in the alleyways - both introduced in the year of the tree planting. The chemical protection was carried out according to the up-to-date recommendations of the Orchard Protection Program.

In the years 2001-2012, the tree growth, bloom abundance, yield per tree and crop efficiency coefficient, as well as mean fruit weight were assessed. For the purpose of data collection, the harvest of each cultivar was done following a singlepicking schedule, and the pears from each tree were collected into separate boxes. In order to determine crop quality, a sample of 20 fruits per each tree was taken. In 2006-2012, the blooming intensity were registered for every experimental tree, using a $0-5$ scale ( 0 - no flowers, 5 - very abundant bloom). Each year in mid-October, the extent of vegetative growth was assessed by measuring the trunk circumferences $20 \mathrm{~cm}$ above the bud union, and calculating the TCSA values, as well as their two-year increments. In autumn 2012, the tree height and canopy width in two directions were recorded. The volume of canopy was calculated using a formula for cone volume. The last set of TCSA together with the 2002-2012 yield sums were used for the calculation of crop efficiency coefficients (CEC), which were obtained at the end of the study.

The collected experimental data were subjected to statistical analysis based on the analysis of variance (ANOVA) approach involving a model appropriate for the randomized block design. Significant differences at $p=0.05$ level were obtained using the Duncan's multiple range test. 


\section{RESULTS AND DISCUSSION}

Until the twelfth year after the orchard planting, the vegetative growth of the investigated pear trees was significantly affected by both the cultivar and the type of nursery trees (Table 1). The 'Dicolor' pear trees were showing significantly stronger growth than 'Carola' pear trees. A similar relationship was noted by Paprštein et al. (2013) and Sosna and Czaplicka-Pędzich (2013). In contrast, in a study by Błaszczyk (2005), the trunks developed by 'Carola' trees on the quince $S_{1}$ were thicker in comparison to the trunks of 'Dicolor'. The trees planted as one-year-old maidens were characterized by the strongest vigor, while the ones planted as two-year-old trees showed weaker growth, which was especially pronounced in 'Dicolor'. In the spring of 2001, the annual grafts were significantly thinner, and after twelve years of experiment, they had the same growth (expressed in TCSA and canopy volume) as originally two-year-old trees of 'Carola' or their growth was greater in 'Dicolor' and equal to the best combination for both cultivars one-year-old maidens (Table 1). These observations are not consistent with those reported by other authors (Deckers \& Schoofs 2001; Bielicki et al. 2004; Lewko et al. 2006; Sadowski et al. 2007; Lipecki et al. 2013). This discrepancy is probably due to the poor quality of the two-year-old stock, which lacked lateral branches and, in the case of 'Dicolor', it consisted of rather thin specimens. In fact, none of the planted trees had laterals, which is unsurprising, given the limited branching capacity showed by certain pear cultivars (Jacyna 2004). Moreover, the root systems of the older trees could be exposed to greater damage, resulting in higher post-transplantation stress. Poniedziałek et al. (1996), Robinson (2003), Bielicki et al. (2004) and Song et al. (2013) agreed that the growth intensity shown by trees planted in an orchard is substantially higher in case of branched trees than in the case of ones that lack laterals, assuming that the both types of transplants are of the same age. In the course of the twelve years of presented research, trees planted as unfeathered maidens grew stronger (TCSA for 'Carola', canopy volume) in comparison to annual grafts. Similar data, pertaining to trunk cross-sectional area, are given by Gudarowska \& Szewczuk (2003).

Table 1. Vegetative growth of two pear cultivars depending on type of nursery trees

\begin{tabular}{lcccc}
\hline \multirow{2}{*}{ Type of nursery trees } & \multicolumn{2}{c}{ Trunk cross-sectional area TCSA $\left(\mathrm{cm}^{2}\right)$} & Canopy volume $\left(\mathrm{m}^{3}\right)$ \\
\cline { 2 - 4 } & Spring 2001 & Autumn 2012 & Increment 2010-2012 & Autumn 2012 \\
\hline 'Carola' & & & & \\
\hline two-year-old trees & $1.8^{\mathrm{c}^{\mathrm{b}}} \pm 0.2$ & $60.3^{\mathrm{a}} \pm 4.8$ & $12.8^{\mathrm{a}} \pm 0.9$ & $2.4^{\mathrm{a}} \pm 0.3$ \\
one-year-old maidens & $1.4^{\mathrm{b}} \pm 0.1$ & $75.9^{\mathrm{b}} \pm 6.8$ & $16.9^{\mathrm{b}} \pm 1.8$ & $3.4^{\mathrm{b}} \pm 0.2$ \\
annual grafts & $0.6^{\mathrm{a}} \pm 0.1$ & $56.5^{\mathrm{a}} \pm 3.8$ & $15.3^{\mathrm{ab}} \pm 1.0$ & $2.4^{\mathrm{a}} \pm 0.1$ \\
\hline 'Dicolor' & & & & $2.7^{\mathrm{a}} \pm 0.2$ \\
\hline two-year-old trees & $1.3^{\mathrm{b}} \pm 0.1$ & $74.0^{\mathrm{a}} \pm 6.4$ & $16.6^{\mathrm{a}} \pm 1.7$ & $4.2^{\mathrm{c}} \pm 0.4$ \\
one-year-old maidens & $1.2^{\mathrm{b}} \pm 0.1$ & $98.8^{\mathrm{b}} \pm 6.3$ & $22.1^{\mathrm{b}} \pm 1.7$ & $3.5^{\mathrm{b}} \pm 0.2$ \\
annual grafts & $0.5^{\mathrm{a}} \pm 0.1$ & $92.5^{\mathrm{b}} \pm 4.9$ & $19.7^{\mathrm{ab}} \pm 1.1$ & $2.7^{\mathrm{a}}$ \\
\hline Mean for cultivar & & & & $3.5^{\mathrm{b}}$ \\
\hline 'Carola' & $1.3^{\mathrm{b}}$ & $64.2^{\mathrm{a}}$ & $15.0^{\mathrm{a}}$ & $19.5^{\mathrm{b}}$ \\
'Dicolor' & $1.0^{\mathrm{a}}$ & $88.4^{\mathrm{b}}$ & & $2.6^{\mathrm{a}}$ \\
\hline Mean for type of tree & & & $14.7^{\mathrm{a}}$ & $3.8^{\mathrm{c}}$ \\
\hline two-year-old trees & $1.6^{\mathrm{c}}$ & $67.2^{\mathrm{a}}$ & $19.5^{\mathrm{b}}$ & $3.0^{\mathrm{b}}$ \\
one-year-old maidens & $1.3^{\mathrm{b}}$ & $87.4^{\mathrm{c}}$ & $17.5^{\mathrm{b}}$ & \\
annual grafts & $0.6^{\mathrm{a}}$ & $74.5^{\mathrm{b}}$ & & \\
\hline
\end{tabular}

* Means followed by the same letter do not differ at $\mathrm{p}=0.05$ according to the Duncan's test; means $\pm \mathrm{SD}(\mathrm{n}=4)$ 
Table 2. Blooming intensity of two pear cultivars depending on type of nursery trees (in $0-5$ scale)

\begin{tabular}{lccccccc}
\hline Type of nursery trees & 2006 & 2007 & 2008 & 2009 & 2010 & 2011 & 2012 \\
\hline 'Carola' & & & & & & & \\
\hline two-year-old trees & $1.6^{\mathrm{a}^{\mathrm{a}}} \pm 0.1$ & $3.6^{\mathrm{a}} \pm 0.4$ & $2.0^{\mathrm{a}} \pm 0.2$ & $3.7^{\mathrm{a}} \pm 0.1$ & $2.1^{\mathrm{a}} \pm 0.3$ & $2.2^{\mathrm{a}} \pm 0.5$ & $2.6^{\mathrm{a}} \pm 0.2$ \\
one-year-old maidens & $1.7^{\mathrm{a}} \pm 0.3$ & $3.4^{\mathrm{a}} \pm 0.0$ & $2.2^{\mathrm{a}} \pm 0.1$ & $3.8^{\mathrm{a}} \pm 0.3$ & $1.8^{\mathrm{a}} \pm 0.4$ & $1.9^{\mathrm{a}} \pm 0.4$ & $2.2^{\mathrm{a}} \pm 0.4$ \\
annual grafts & $1.8^{\mathrm{a}} \pm 0.3$ & $3.2^{\mathrm{a}} \pm 0.3$ & $2.3^{\mathrm{a}} \pm 0.4$ & $3.7^{\mathrm{a}} \pm 0.1$ & $2.3^{\mathrm{a}} \pm 0.4$ & $2.3^{\mathrm{a}} \pm 0.4$ & $2.3^{\mathrm{a}} \pm 0.3$ \\
\hline 'Dicolor' & & & & & & & \\
\hline two-year-old trees & $3.1^{\mathrm{a}} \pm 0.2$ & $3.3^{\mathrm{a}} \pm 0.1$ & $2.8^{\mathrm{a}} \pm 0.1$ & $2.8^{\mathrm{b}} \pm 0.5$ & $2.6^{\mathrm{a}} \pm 0.2$ & $1.0^{\mathrm{a}} \pm 0.1$ & $1.9^{\mathrm{a}} \pm 0.2$ \\
one-year-old maidens & $3.4^{\mathrm{a}} \pm 0.1$ & $2.9^{\mathrm{a}} \pm 0.3$ & $3.9^{\mathrm{b}} \pm 0.2$ & $1.4^{\mathrm{a}} \pm 0.5$ & $3.5^{\mathrm{b}} \pm 0.2$ & $1.1^{\mathrm{a}} \pm 0.3$ & $1.3^{\mathrm{a}} \pm 0.4$ \\
annual grafts & $3.6^{\mathrm{a}} \pm 0.1$ & $2.7^{\mathrm{a}} \pm 0.3$ & $3.5^{\mathrm{ab}} \pm 0.1$ & $1.7^{\mathrm{a}} \pm 0.3$ & $3.2^{\mathrm{ab}} \pm 0.2$ & $0.7^{\mathrm{a}} \pm 0.2$ & $1.1^{\mathrm{a}} \pm 0.4$ \\
\hline Mean for cultivar & & & & & & & \\
\hline 'Carola' & $1.7^{\mathrm{a}}$ & $3.4^{\mathrm{b}}$ & $2.2^{\mathrm{a}}$ & $3.7^{\mathrm{b}}$ & $2.1^{\mathrm{a}}$ & $2.1^{\mathrm{b}}$ & $2.4^{\mathrm{b}}$ \\
'Dicolor' & $3.4^{\mathrm{b}}$ & $3.0^{\mathrm{a}}$ & $3.4^{\mathrm{b}}$ & $2.0^{\mathrm{a}}$ & $3.1^{\mathrm{b}}$ & $0.9^{\mathrm{a}}$ & $1.4^{\mathrm{a}}$ \\
\hline Mean for type of tree & & & & & & & \\
\hline two-year-old trees & $2.4^{\mathrm{a}}$ & $3.4^{\mathrm{a}}$ & $2.4^{\mathrm{a}}$ & $3.3^{\mathrm{a}}$ & $2.4^{\mathrm{a}}$ & $1.6^{\mathrm{a}}$ & $2.3^{\mathrm{b}}$ \\
one-year-old maidens & $2.6^{\mathrm{a}}$ & $3.2^{\mathrm{a}}$ & $3.1^{\mathrm{b}}$ & $2.6^{\mathrm{a}}$ & $2.7^{\mathrm{a}}$ & $1.5^{\mathrm{a}}$ & $1.8^{\mathrm{ab}}$ \\
annual grafts & $2.7^{\mathrm{a}}$ & $3.0^{\mathrm{a}}$ & $2.9^{\mathrm{ab}^{\mathrm{a}}}$ & $2.7^{\mathrm{a}}$ & $2.8^{\mathrm{a}}$ & $1.5^{\mathrm{a}}$ & $1.7^{\mathrm{a}}$ \\
\hline
\end{tabular}

* For explanations see Table 1

Table 3. Yielding, crop efficiency coefficient and mean fruit weight of two pear cultivars depending on type of nursery trees

\begin{tabular}{lccc}
\hline \multirow{2}{*}{ Type of nursery trees } & Cumulative yield $\left(\mathrm{kg} \mathrm{tree}^{-1}\right)$ & $\mathrm{CEC}\left(\mathrm{kg} \cdot \mathrm{cm}^{-2}\right)$ & Mean fruit weight $(\mathrm{g})$ \\
\cline { 2 - 4 } 'Carola' & $2003-2012$ & $2001-2012$ & $2003-2012$ \\
\hline two-year-old trees & $103.5^{\mathrm{ab}^{*}} \pm 4.3$ & $1.72^{\mathrm{a}} \pm 0.14$ & $225^{\mathrm{a}} \pm 11$ \\
one-year-old maidens & $111.5^{\mathrm{b}} \pm 9.9$ & $1.47^{\mathrm{a}} \pm 0.18$ & $216^{\mathrm{a}} \pm 9$ \\
annual grafts & $83.4^{\mathrm{a}} \pm 9.3$ & $1.48^{\mathrm{a}} \pm 0.22$ & $232^{\mathrm{a}} \pm 10$ \\
\hline 'Dicolor' & & & $181^{\mathrm{a}} \pm 7$ \\
\hline two-year-old trees & $102.9^{\mathrm{ab}} \pm 10.8$ & $1.39^{\mathrm{b}} \pm 0.19$ & $179^{\mathrm{a}} \pm 9$ \\
one-year-old maidens & $112.3^{\mathrm{b}} \pm 12.8$ & $1.14^{\mathrm{ab}} \pm 0.10$ & $177^{\mathrm{a}} \pm 6$ \\
annual grafts & $89.3^{\mathrm{a}} \pm 8.4$ & $0.97^{\mathrm{a}} \pm 0.12$ & $224 \mathrm{~b}$ \\
\hline Mean for cultivar & & & $179 \mathrm{a}$ \\
\hline 'Carola' & $99.5 \mathrm{a}$ & $1.56 \mathrm{~b}$ & $203 \mathrm{a}$ \\
'Dicolor' & $101.6 \mathrm{a}$ & $1.17 \mathrm{a}$ & $198 \mathrm{a}$ \\
\hline Mean for type of tree & $103.3 \mathrm{~b}$ & $1.56 \mathrm{~b}$ & $204 \mathrm{a}$ \\
\hline two-year-old trees & $111.9 \mathrm{~b}$ & $1.31 \mathrm{a}$ & $1.23 \mathrm{a}$ \\
one-year-old maidens & $86.4 \mathrm{a}$ & & \\
annual grafts & & & \\
\hline
\end{tabular}

* For explanations see Table 1

The bloom abundance in the 2006-2012 period was mostly influenced by the yield in the preceding year (Table 2). Of the two cultivars, 'Carola' was showing a less regular flowering pattern - the years of abundant and weak bloom were alternating with each other. The only exception was the year 2011. Strong frosts up to $-24{ }^{\circ} \mathrm{C}$, which occurred during the winter of 2010/2011, caused poor flowering and led to bud damage in both of the cultivars. The flowering regularity of the trees in each year did not differ substantially across the cultivars. Statistically significant differences among the bloom abundances in relation to the type of the nursery trees were noted only in 2008-2010 for 'Dicolor'. In 2008 
and 2010, the bloom of the one-year-old maidens was more intensive in comparison to the two-yearold trees, whereas in 2009, the trees planted as twoyear-old nursery stock showed most abundant flowering. According to Song et al. (2013), the number of flowers developed by apple trees in the third year after planting was significantly higher in case of branched trees than unbranched ones. Similar data, regarding the two-year-old 'Fiesta' apple stock, were reported by Gudarowska and Szewczuk (2006).

In the presented experiment, the pear trees, irrespective of the cultivar, started to bear fruit in the third year after planting, and the obtained yields were much higher than in the Błaszczyk (2005) experiment (Table 3). The total 2003-2012 yield was not high because of the extensive frost damages, which occurred in the years 2007, 2010 and 2012 , when temperatures plummeted to -3 to $-4{ }^{\circ} \mathrm{C}$ during the peak of tree flowering. The greatest losses were noted in 2011, when a spring frost of $-5^{\circ} \mathrm{C}$ between May 3 and 6 (end of the bloom) damaged the flowers and fruitlets, especially of ' $\mathrm{Di}$ color'. Until the twelfth year after the orchard planting, the two-year-old pear trees without feathers did not crop better than the one-year-old maidens. The final results of the study proved that the yields were similar across the two groups. Taking into consideration the means for type of tree, the grafted trees yielded much worse than the budded ones, and their crop efficiency indices were the lowest (at the level of the one-year-old maidens), as confirmed by Robinson (2003) with apple trees. Different results were obtained by Gudarowska \& Szewczuk (2003). In their experiment, the grafted apple stock gave higher crops in comparison with budded maidens. In the experiment by Bielicki et al. (2004), the cropping levels of annual grafts and one-year-old apple trees without branches did not differ to a substantial degree. According to several authors, the branching status of nursery stock is more important than its age. The high productivity of trees with developed lateral branches at the time of planting is mentioned in numerous studies (Green 1991; Poniedziałek et al. 1996; Gudarowska \& Szewczuk 2006; Sadowski et al. 2007; Robinson et al. 2014). According to Pietranek \& Jadczuk (2006), the planting of one-year- old maiden apple trees with feathers may lead to similar yields, as in the case of same trees left in a nursery for one more year and just then planted.

The pear tree cultivars investigated in the experiment differed significantly in mean fruit weight (Table 3). The heavier fruits were obtained from the 'Carola' trees $(224 \mathrm{~g})$ versus $179 \mathrm{~g}$ for 'Dicolor'. Sosna \& Czaplicka-Pędzich (2013) got similar results. Contrary to this, in other experiments (Błaszczyk 2005; Paprštein 2008), 'Dicolor' fruits were much smaller. The full red blush developed by the fruits of 'Dicolor' places it among the most attractive pear cultivars. The type of nursery trees had no significant influence on the mean fruit weight. Also, in the experiment of Słowiński \& Sadowski (2000), this factor did not affect the mean apple weight obtained in the third year after planting in the orchard. However, such an influence had been observed one year before. The trees planted at the age of one year developed larger fruits than the trees grown from the two-year-old stock, which might have been caused due to the poorer yielding of the former.

\section{CONCLUSIONS}

1. Results of the twelve years of the study prove that the investigated two pear cultivars are suitable for commercial production. 'Carola' and 'Dicolor' budded on the quince $S_{1}$ rootstock gave high and early yields of fruits with a good mean weight. The productivity of these cultivars would have been higher if not for the damage caused by the spring frosts.

2. The type of planting material had a significant influence on tree growth and cropping in the orchard. The trees planted as one-year-old maidens were characterized by stronger growth and gave similar yields as those grown from two-year-old non-feathered material. For this reason, establishment of orchards from older trees without lateral branches cannot be recommended.

3. Taking into consideration the mean yields, 'Carola' and 'Dicolor' pears planted as annual grafts yielded the worst, thus planting of thick feathered trees may be a more economically justified option.

4. The type of nursery trees had no influence on the mean fruit weight, regardless of the cultivar. 


\section{REFERENCES}

Bielicki P., Czynczyk A., Nowakowski S. 2004. Growth and yield of apple 'Szampion' cultivar in dependence from the quality of planting material. Folia Universitatis Agriculturae Stetinensis. Agricultura 240(96): 21-24. [in Polish with English abstract]

Błaszczyk J. 2005. Porównanie wzrostu i początkowego plonowania czterech odmian grusz. XXV Międzynarodowe Seminarium Sadownicze, Limanowa, p. 71-73. [in Polish]

Czynczyk A. 1989. Wpływ jakości i wieku sadzonych drzewek jabłoni na przydatność sadowniczą. Ogrodnictwo 3: 10-13. [in Polish]

Deckers T., Schoofs H. 2001. Management of high density pear orchards. The Compact Fruit Tree 34(4): $117-120$.

Elfving D.C., Visser D.B. 2005. Cyclanilide induces lateral branching in apple trees. HortScience 40(1): 119-122.

Elkins R.B., Klonsky K., DeMoura R., DeJong T.M. 2008. Economic evaluation of high density versus standard orchard configurations; case study using performance data for 'Golden Russet Bosc' pears. Acta Horticulturae 800: 739-746. DOI: 10.17660/ActaHortic.2008.800.101.

Ferree D.C. 1976. Effect of rootstocks, propagation method and transplanting on growth and flowering of young apple trees. Journal of the American Society for Horticultural Science 101(6): 676-678.

Green G.M. 1991. The advantage of feathered trees for more rapid cropping in apples. Pennsylvania Fruit News 71(4): 25-28.

Gudarowska E., Szewczuk A. 2003. Comparison of grafted apple trees with maidens after planting to the orchard. Folia Horticulturae 15(2): 131-136.

Gudarowska E., Szewczuk A. 2006. Yielding of apple tree cvs. 'Fiesta' and 'Pinova' depending on the age of planting material and methods of its production in a nursery. Sodininkysté ir Daržininkysté 25(3): 90-97.

Jacyna T. 2004. The role of cultivar and rootstock in sylleptic shoot formation in maiden pear trees. Journal of Fruit and Ornamental Plant Research 12: 41-47.

Kapłan M. 2010. Effect of growth regulators on the branching ability of maiden apple trees of the 'Šampion' and 'Jonica' cultivars. Folia Horticulturae 22(2): 3-7. DOI: 10.2478/fhort-2013-0152

Lewko J., Sadowski A., Ścibisz K. 2006. Growth of rootstocks for pears and pear cultivars budded on them - in the nursery. Latvian Journal of Agronomy 9: 80-83.
Lipecki J., Jacyna T., Lipa T., Szot I. 2013. The quality of apple nursery trees of knip-boom type as affected by the methods of propagation. Acta Scientiarum Polonorum. Hortorum Cultus 12(6): 157-165.

Oosten van H.J. 1978. Effect of initial tree quality on yield. Acta Horticulturae 65: 123-125. DOI: 10.17660/ActaHortic.1978.65.19.

Paprštein F. 2008. Prospective pear cultivars bred in the Czech Republic. Acta Horticulturae 800: 343-348. DOI: 10.17660/ActaHortic.2008.800.43.

Paprštein F., Matejicek A., Sedlak J. 2013. New pear cultivars from the Czech Republic. Acta Horticulturae 976: 147-151. DOI: 10.17660/ActaHortic.2013.976.18.

Pietranek A., Jadczuk E. 2006. Growth and bearing of 'Jonagold' apple trees as affected by rootstock and type of nursery trees used for planting. Latvian Journal of Agronomy 9: 103-108.

Poniedziałek W., Porębski S., Gąstoł M. 1996. Korelacje między pomiarami fitometrycznymi okulantów odmian 'Melrose' i 'Gloster' a ich wzrostem i plonowaniem w sadzie. Materiały XXXIV Ogólnopolskiej Naukowej Konferencji Sadowniczej, Skierniewice, p. 137-142. [in Polish]

Robinson T.L. 2003. Effect of apple tree caliper and feathering on yield and orchard economics. HortScience 38(5): 740.

Robinson T.L., Black B., Cowgill W. 2014. Use of multiple applications of Maxcel and Promalin to produce feathered trees. Compact Fruit Tree 47(1): 23-28.

Sadowski A., Mackiewicz M., Dziuban R. 2007. Growth and early bearing of apple trees as affected by the type of nursery trees used for planting. Acta Horticulturae 732: 447-455. DOI: 10.17660/ActaHortic.2007.732.68.

Sazo M.M., Robinson T.L. 2011. The use of plant growth regulators for branching of nursery trees in NY state. New York Fruit Quarterly 19(2): 5-9.

Słowiński A., Sadowski A. 2000. Growth and cropping of 'Elstar' apple trees depending on the kind of nursery stock used for planting. Zeszyty Naukowe Instytutu Sadownictwa i Kwiaciarstwa 8: 59-66. [in Polish with English abstract]

Song C., Yu G., Zhang Q., Xing L., Song X., Zhao C., Han M., Li G. 2013. Effects of nursery type and planting date on vegetative growth characteristics of the young apple trees. Journal of Fruit Science 1: 92-96.

Sosna I. 2007. Uprawa gruszy. Plantpress, Kraków, p. 35-36. [in Polish]

Sosna I., Czaplicka-Pędzich M. 2013. Growth and fruiting of trees on six pear cultivars depending on applied rootstock. Episteme 20(3): 441-451. [in Polish with English abstract] 